\title{
BMJ Open Association between adolescent tobacco, alcohol and illicit drug use and individual and environmental resilience protective factors
}

\author{
Rebecca Kate Hodder, ,2,3,4 Megan Freund, 2,3,4 Jenny Bowman,, 3,5 \\ Luke Wolfenden, ${ }^{1,2,3,4}$ Karen Gillham, ${ }^{1,3}$ Julia Dray, ${ }^{1,3,5}$ John Wiggers ${ }^{1,2,3,4}$
}

To cite: Hodder RK, Freund M, Bowman J, et al. Association between adolescent tobacco, alcohol and illicit drug use and individual and environmental resilience protective factors. BMJ Open 2016;6:e012688. doi:10.1136/bmjopen-2016012688

- Prepublication history and additional material is available. To view please visit the journal (http://dx.doi.org/ 10.1136/bmjopen-2016012688).

Received 17 May 2016 Revised 28 September 2016 Accepted 3 October 2016

CrossMark

For numbered affiliations see end of article.

Correspondence to Rebecca Kate Hodder; Rebecca.hodder@hnehealth. nsw.gov.au

\section{ABSTRACT}

Objectives: Research suggests that individual and environmental resilience protective factors may be associated with adolescent substance use; however, the associations between a broad range of such factors and use of various types of substances have not been examined. The study aimed to determine the association between a comprehensive range of adolescent individual and environmental resilience protective factors and measures of tobacco, alcohol and illicit substance use.

Design: Cross-sectional study.

Setting: 32 Australian secondary schools.

Participants: Grade 7-10 students (aged 11-17 years).

Measures: Data regarding 14 student individual and environmental resilience protective factors and seven substance use measures (tobacco, alcohol, marijuana, other illicit drug use) were obtained via an online selfreport survey. Adjusted multivariate logistic regression analyses examined the association between all student resilience protective factors and seven substance use measures.

Results: Inverse univariate associations were found for 94 of 98 relationships examined ( $n=10092)$. Multivariate analyses found: consistent inverse associations between 2 of 14 protective factors and all substance use measures ('goals and aspirations', 'prosocial peers'); inverse associations between 4 protective factors with multiple substance use measures ('home support' (5 of 7), 'school support' (3 of 7), 'self-awareness' (2 of 7), 'community meaningful participation' (2 of 7)); positive associations between 2 resilience protective factors with multiple measures of substance use ('community support' (3 of 7), 'peer caring relationships' (5 of 7)) and 6 protective factors not to be associated with any substance use measure.

Conclusions: Despite individual relationships between the majority of resilience protective factors and substance use types, the protective benefit of such factors for adolescent substance use was limited to only a small number of such factors when considered collectively. Such results suggest that interventions seeking to reduce adolescent substance use may need

\section{Strengths and limitations of this study}

- This study represents the most comprehensive examination of the associations between a broad range of individual and environmental resilience protective factors and multiple measures of adolescent substance use.

- Design strengths of the study include: a large sample of adolescents, comprehensive measurement of individual and environmental resilience protective factors using a tool validated in an Australian population, use of multiple accepted measures of substance use, and analyses that accounted for a range of known confounders, potential clustering effects within schools and sensitivity analyses of data with imputation for missing data.

- Although the study was reliant on adolescent self-report of substance use and subject to the known limitations of self-report in this population, strategies to increase the validity of adolescent report were used including a web-based survey and confidential participation by students.

- While a non-response bias may exist, consistency of results with comparative national data suggests that the likelihood of such bias may be limited.

- The cross-sectional design of the study does not allow for investigation of causal pathways of the associations between resilience protective factors and adolescent substance use.

to target specific protective factors to address specific types of substance use.

Trial registration number: ACTRN12611000606987, Results.

\section{BACKGROUND}

Tobacco, alcohol and illicit substance use are responsible for more than $12 \%$ of deaths worldwide $^{1}$ and cost more than US\$600 billion annually in the $\mathrm{USA}^{2-5}$ and US $\$ 46.5$ 
billion in Australia. ${ }^{6}$ Initiation of tobacco, alcohol and illicit substance use in high-income countries primarily occurs during adolescence. ${ }^{7-9}$ The younger the age of initiation of substance use, the greater the likelihood of ongoing use, dependence and harm in later life. ${ }^{7}{ }^{10-12}$ In the USA, the UK and Australia, between 23\% and $45 \%$ of adolescents (aged 11-17 years) have smoked a cigarette,$^{9} 1314$ 43-74\% have consumed an alcoholic drink, ${ }^{9} 13 \quad 1422-29 \%$ have consumed at least five alcoholic drinks on one occasion ${ }^{9}{ }^{13}$ and between $15 \%$ and $40 \%$ have taken an illicit substance. ${ }^{9} 1314$ The prevention of substance use among adolescents is a recommended strategy for reducing substance use-related harms throughout the lifecourse. ${ }^{15-17}$

Historically, research regarding the determinants of adolescent substance use has focused on risk factors such as access to substances, socioeconomic disadvantage and substance use by parents, peers and siblings. ${ }^{18-22}$ More recent research has explored a range of factors that may be protective of adolescent substance use, ${ }^{23}$ including individual factors such as self-esteem ${ }^{23-26}$ and problem-solving ability, ${ }^{27}$ and environmental factors such as connection to school, ${ }^{232628-33}$ family, ${ }^{19} 23262834$ and prosocial peers. ${ }^{34}{ }^{35}$ Such factors have been considered to be factors protective of an adolescents' 'resilience', ${ }^{25}{ }^{36-41}$ broadly described as a process, capacity or outcome of successfully adapting to challenging or threatening life circumstances. ${ }^{42-44}$ As a consequence, enhancement of such protective factors is recommended as a strategy for reducing adolescent substance use. ${ }^{15-17}$ The specific protective factors to be addressed by such interventions, however, are only broadly defined or are limited to a few examples in such recommendations. ${ }^{15-17}$

Although considerable research has been reported regarding the association between adolescent resilience protective factors and adolescent substance use, ${ }^{23}$ 27-30 32 45-65 such research using multivariate analyses has only considered a limited number of resilience protective factors (six at most ${ }^{46}$ ) or created aggregate scores of such factors, ${ }^{65}$ with the latter precluding assessment of associations for particular factors. In such studies, inconsistency of findings is apparent in terms of the presence and direction of the associations between resilience protective factors and substance use. For example, adolescents have been reported to be either less, more, or no more or less likely to use a substance if they have low self-esteem, ${ }^{23} 5463$ low school connectedness ${ }^{23} 282932$ or low academic aspirations. ${ }^{28} 47505861$ Inconsistency is similarly evident between substances in their reported association with specific protective factors. For example, in one study a significant negative association was reported between educational aspirations and alcohol and marijuana use, but not tobacco use. ${ }^{50}$ In other studies, significant negative associations have been reported between community involvement and tobacco and marijuana use, but not alcohol use. ${ }^{49}$ Such contrasting findings between studies may be attributable, in part, to the different measures of such factors across studies, and to the inconsistent inclusion of protective factors.

To date, no peer-reviewed study has reported the associations between a comprehensive range of adolescent individual and environmental resilience protective factors and multiple types of substance use. To address this gap and provide information that may guide future development of interventions targeting adolescent substance use, a study was conducted to determine the association between 14 adolescent individual and environmental resilience protective factors and seven measures of tobacco, alcohol and illicit substance use in a population of Australian adolescents.

\section{METHODS}

\section{Study design and setting}

A cross-sectional study was conducted in one Health District of New South Wales, Australia. The District encompasses metropolitan, regional, rural and remote areas with a population of $\sim 114000$ people aged 10-19 years. ${ }^{66}$ The data were collected as baseline data for a randomised controlled trial for which ethics and other study approvals were obtained. The methods of the larger study are described in detail elsewhere. ${ }^{67}$

\section{Participants and recruitment \\ Secondary schools}

Eligible schools were either Government or Catholic secondary schools located in a disadvantaged Local Government Area, ${ }^{68}$ with enrolments in Grades 7-10 (typically aged 12-16 years) on one campus, and with more than 400 total student enrolments. Independent, special needs, selective, central (schools catering for children aged 4-18 years), boarding schools or schools that were not coeducational were ineligible.

Eligible schools were approached for study participation according to a randomly ordered list of schools. If a school declined, the next school was invited to participate until a quota of 32 schools was recruited.

\section{Students}

All students enrolled in Grade 7 (usually aged 12-13 years) to Grade 10 (usually aged $15-16$ years) in the 32 selected schools were eligible to participate $(n=18310)$. Parents of students were mailed a study information sheet, a consent form and a reply paid envelope. Two weeks following, non-responding parents were telephoned by school-affiliated staff to prompt return of the consent form.

\section{Data collection procedures}

Students with parental consent were invited to complete a self-report anonymous web-based survey in class time (August-November 2011). 


\section{Measures}

Student and school characteristics

Student age, school grade, sex, Aboriginal and Torres Strait Islander status and residential postcode were collected via the student survey.

\section{Substance use}

Students reported tobacco, alcohol, marijuana and other illicit drug use (seven outcomes) via the web-based survey (table 1). The substance use items were sourced from a national triennial survey of school students' health behaviours. ${ }^{9}$

\section{Resilience protective factors}

The Resilience and Youth Development module of the California Healthy Kids Survey, a measure of 14 adolescent individual and environmental resilience protective factors (termed internal and environmental assets), was

Table 1 Student substance use and resilience protective factor items

\begin{tabular}{|c|c|c|c|}
\hline & Indicator & Survey item & Response options \\
\hline \multicolumn{4}{|l|}{ Substance use } \\
\hline \multirow[t]{2}{*}{ Tobacco } & Ever use & Have you ever smoked even part of a cigarette? ${ }^{9}$ & Yes/No \\
\hline & Recent use & Have you smoked a cigarette in the last week? & Yes/No \\
\hline \multirow[t]{3}{*}{ Alcohol } & Ever use & $\begin{array}{l}\text { Have you ever had a drink of alcohol? For example, beer, wine } \\
\text { or alcopops/premix drinks (do not count sips or tastes) }\end{array}$ & Yes/No \\
\hline & Recent use & $\begin{array}{l}\text { Have you had any alcoholic drinks, such as beer, wine or } \\
\text { alcopops/premix drinks in the last week? (do not count sips or } \\
\text { tastes) }\end{array}$ & Yes/No \\
\hline & 'Risky' use & $\begin{array}{l}\text { In the last } 4 \text { weeks, how many times have you had } 5 \text { or more } \\
\text { alcoholic drinks in a row? }{ }^{9}\end{array}$ & $\begin{array}{l}\text { None/Once/Twice/3-6 } \\
\text { times/7 or more times }\end{array}$ \\
\hline Marijuana & Recent use & $\begin{array}{l}\text { How many times in the last } 4 \text { weeks have you smoked or used } \\
\text { marijuana/cannabis (grass, hash, dope, weed, mull, yarndi, } \\
\text { ganga, pot, a bong, a joint) }{ }^{9}\end{array}$ & $\begin{array}{l}\text { None/Once or twice/ } \\
3-5 \text { times/6-9 times/ } \\
10-19 \text { times/20-39 } \\
\text { times/40 or more times }\end{array}$ \\
\hline $\begin{array}{l}\text { Other illicit } \\
\text { drugs }\end{array}$ & Recent use & $\begin{array}{l}\text { How many times in the last } 4 \text { weeks have you used any other } \\
\text { illegal drug or pill to get 'high', such as inhalants, hallucinogens } \\
\text { (eg, LSD, acid, trips), amphetamines (eg, speed, ice), ecstasy, } \\
\text { cocaine or heroin? }\end{array}$ & $\begin{array}{l}\text { None/Once or twice/ } \\
3-5 \text { times/6-9 times/ } \\
10-19 \text { times/20-39 } \\
\text { times/40 or more times }\end{array}$ \\
\hline \multicolumn{4}{|c|}{ Resilience protective factors } \\
\hline \multirow[t]{6}{*}{ Individual } & $\begin{array}{l}\text { Cooperation and } \\
\text { communication }\end{array}$ & $\begin{array}{l}2 \text { items; eg, 'I enjoy working together with other students my } \\
\text { age' }\end{array}$ & $\begin{array}{l}\text { 1: Never true, } 2: \text { True } \\
\text { some of the time; } 3: \\
\text { True most of the time; } \\
\text { 4: True all of the time }\end{array}$ \\
\hline & Self-efficacy & 4 items; eg, 'I can do most things if I try' & As above \\
\hline & Empathy & $\begin{array}{l}3 \text { items; eg, 'I try to understand what other people feel and } \\
\text { think' }\end{array}$ & As above \\
\hline & Problem-solving & 3 items; eg, 'When I need help I find someone to talk with' & As above \\
\hline & Self-awareness & 3 items; eg, 'I understand why I do what I do' & As above \\
\hline & $\begin{array}{l}\text { Goals and } \\
\text { aspirations }\end{array}$ & 3 items; eg, 'I have goals and plans for the future' & As above \\
\hline \multirow[t]{8}{*}{ Environmental } & School support & $\begin{array}{l}6 \text { items; eg, 'At my school there is an adult who really cares } \\
\text { about me' }\end{array}$ & As above \\
\hline & $\begin{array}{l}\text { School meaningful } \\
\text { participation }\end{array}$ & $\begin{array}{l}3 \text { items; eg, 'At my school, I help decide things like class } \\
\text { activities or rules' }\end{array}$ & As above \\
\hline & $\begin{array}{l}\text { Community } \\
\text { support }\end{array}$ & $\begin{array}{l}6 \text { items; eg, 'Outside of school and home, there is an adult } \\
\text { whom I trust' }\end{array}$ & As above \\
\hline & $\begin{array}{l}\text { Community } \\
\text { meaningful } \\
\text { participation }\end{array}$ & $\begin{array}{l}3 \text { items; eg, 'I am part of clubs, sports teams, church/temple or } \\
\text { other groups' }\end{array}$ & As above \\
\hline & Home support & $\begin{array}{l}6 \text { items; eg, 'At home, there is an adult who listens to me when } \\
\text { I have something to say' }\end{array}$ & As above \\
\hline & $\begin{array}{l}\text { Home meaningful } \\
\text { participation }\end{array}$ & $\begin{array}{l}3 \text { items; eg, 'I do fun things or go fun places with my parents or } \\
\text { other adult from my home' }\end{array}$ & As above \\
\hline & $\begin{array}{l}\text { Peer caring } \\
\text { relationships }\end{array}$ & $\begin{array}{l}3 \text { items; eg, 'I have a friend who helps me when I am having a } \\
\text { hard time' }\end{array}$ & As above \\
\hline & Prosocial peers & 3 items; eg, 'My friends try to do what is right' & As above \\
\hline
\end{tabular}


used to measure protective factors (51 items: 4-point Likert Scale-'1: Never true' to '4: True all of the time'). ${ }^{69}$ The survey incorporates items that addressed six individual factor subscales and eight environmental factor subscales (table 1). ${ }^{69}$ Two minor modifications were made to the survey for use in an Australian population. First, the survey item 'I plan to go to college...' was modified to state 'I plan to go to university or Technical and Further Education ...'. Second, the response options for all of the items from the survey were modified from 'Not at all true, a little true, pretty much true, very much true' to 'Never true, true some of the time, true most of the time, true all of the time'. Consistent with reports from the tool developers, ${ }^{69}$ the data from the current study confirms that the survey tool is an internally consistent and valid measure (Cronbach $\alpha$ coefficients for individual factor subscales: 0.55-0.81; environmental factor subscales: 0.71-0.91). Additionally, confirmatory factor analysis using data from this study demonstrates the individual and environmental subscale factor structure to be a good model fit (Comparative Fit Index 0.92, Standardised Root Mean Square Residual 0.04, Root Mean Square Error of Approximation 0.04, Adjusted Goodness of Fit 0.90); with such results being similar to those reported by the tool developers. ${ }^{69}$

\section{Statistical analysis}

Student characteristics and substance use

Participants who did not answer any substance use items (ie, they started the online survey but dropped out of the survey before getting to the substance use items) were excluded from all analyses $(n=16)$. Participants who did not answer items for a particular substance were excluded from analyses for that particular substance. Consent and participation rates, demographic and substance use data were examined using descriptive statistics. Socioeconomic status and remoteness of residential location were calculated from student-reported residential postcode using the Australia Bureau of Statistics Socio-Economic Indexes for Areas ${ }^{68}$ and the Accessibility/Remoteness Index of Australia, ${ }^{70}$ respectively.

The response options for 'risky' alcohol use were collapsed-'none' vs 'once'/"twice'/'3-6 times'/'7 or more times', as were the response options for marijuana and other illicit drug use-'none' vs 'once or twice'/'3-5 times'/“6-9 times'/'10-19 times'/'20-39 times'/“40 or more times'.

Differences by sex and grade for each of the seven substance use outcomes were assessed through logistic regression analysis via a Generalised Estimating Equation (GEE) framework ${ }^{71} 72$ to account for potential clustering of students within schools.

\section{Resilience protective factors}

Fourteen protective factor scores (six individual factor subscales, eight environmental factor subscales) were created. Protective factor subscale scores were calculated by averaging the responses to all items in a subscale for each student. All such scores ranged from 1 to 4 .

\section{Correlation between resilience protective factors}

Correlation analysis was undertaken to determine the correlations between all individual and environmental resilience protective factors scores. Pearson correlation coefficients were calculated for each.

\section{Associations between resilience protective factors}

\section{and substance use}

To examine the univariate and multivariate associations between resilience protective factors and student substance use, logistic regression analyses were conducted within a GEE framework ${ }^{71} 72$ to account for potential clustering of students within schools. Individual backward stepwise logistic regression models were conducted for each of the seven substance use outcomes (dependent variables) and each factor measure (independent variables: 14 protective factor subscales) to assess whether a decrease in each mean factor score was associated univariately with substance use (98 models). Multivariate logistic regression analyses explored the association between all individual and environmental protective factor subscales (14 in all, 6 individual and 8 environmental) and the seven substance use outcomes (seven models). In all models, factor score was used as a continuous variable (mean score). All models included potential demographic confounders of substance use, including: school size (400-800 medium, >800 large), school type (government/Catholic school) and student characteristics (sex, grade, remoteness of residential location, socioeconomic and Aboriginal/Torres Strait Islander status). ORs and $95 \%$ CIs were calculated for each model. In addition, the odds and probability of use of each substance was derived from the models for specific values of factors (factor score of 2 and 3), in order to calculate the difference in the probability of substance use for a one-unit change in factor score.

Missing data from substance use items were imputed using the recommended method for cross-sectional data in single-item measures-'hot deck' imputation. ${ }^{73}$ Logistic regression analyses were repeated using the imputed data set and any differential results reported.

To account for multiple testing, a criterion for statistical significance of $\mathrm{p} \leq 0.0005$ was used (Bonferroni-corrected).

\section{RESULTS \\ Sample}

Of the 172 eligible secondary schools in the study area, 47 schools were eligible to participate. Across the 32 participating schools (73\% school consent rate), parental consent was granted for 13440 students $(73.4 \%)$ of which 10244 students completed at least part of the student survey (participation rate: $55.9 \%$ of total enrolled students; $76.2 \%$ of students with parental consent). Those students who completed at least one 
substance use item $(\mathrm{n}=10092 ; 55.1 \%)$ are reported in the analysis, the demographic characteristics of whom are shown in table 2 .

\section{Substance use}

Twenty-three per cent of students had ever used tobacco and $7 \%$ had recently used tobacco, with both forms of use increasing by grade (table 3 ), with no difference by sex.

For alcohol use, $51 \%, 14 \%$ and $15 \%$ of students reported having ever used, recently used or 'risky' use of alcohol, respectively. Alcohol use significantly increased by grade across all three measures. A higher proportion of males reported use of each of the three alcohol measures.

Six per cent of students reported recent marijuana use and 3\% reported recent other illicit drug use. Marijuana and other illicit drug use increased by grade, with more males reporting use of marijuana and other illicit drugs.

\begin{tabular}{|c|c|c|}
\hline Student demographics & $\begin{array}{l}\text { Student } \\
\text { sample N (\%) }\end{array}$ & $\begin{array}{l}\text { State } \\
\text { comparison } \\
\text { data } \%^{*}\end{array}$ \\
\hline \multicolumn{3}{|l|}{ Sex } \\
\hline Male & 5066 (50.2) & 51.4 \\
\hline \multicolumn{3}{|l|}{ Grade } \\
\hline Year 7 & 3080 (30.5) & 24.7 \\
\hline Year 8 & 2646 (26.2) & 24.8 \\
\hline Year 9 & 2476 (24.5) & 25.1 \\
\hline Year 10 & $1890(18.7)$ & 25.3 \\
\hline \multicolumn{3}{|l|}{ Age } \\
\hline$<12$ & $11(0.1)$ & 0.4 \\
\hline 12 & 1265 (12.5) & 18.8 \\
\hline 13 & 2926 (29.0) & 24.9 \\
\hline 14 & $2646(26.2)$ & 25.1 \\
\hline 15 & 2215 (22.0) & 24.4 \\
\hline 16 & 1000 (9.9) & 6.2 \\
\hline$>16$ & $29(0.3)$ & 0.2 \\
\hline \multicolumn{3}{|l|}{ Aboriginality } \\
\hline $\begin{array}{l}\text { Aboriginal and/or Torres } \\
\text { Strait Islander }\end{array}$ & $1143(11.3)$ & 5.2 \\
\hline \multicolumn{3}{|l|}{ Socioeconomic statust } \\
\hline $\begin{array}{l}\text { Quintile } 1 \text { (most } \\
\text { disadvantaged) }\end{array}$ & $551(5.5)$ & \\
\hline Quintile 2 & $3000(29.7)$ & \\
\hline Quintile 3 & $5334(52.9)$ & \\
\hline Quintile 4 & $1124(11.1)$ & \\
\hline $\begin{array}{l}\text { Quintile } 5 \text { (least } \\
\text { disadvantaged) }\end{array}$ & $68(0.7)$ & \\
\hline \multicolumn{3}{|l|}{ Remoteness (ARIA)† } \\
\hline Major cities & $4246(42.1)$ & \\
\hline Inner regional & 2856 (28.3) & \\
\hline Outer regional/remote & 2975 (29.5) & \\
\hline
\end{tabular}

*State comparison data for students in Years 7 to 10 attending government and Catholic schools in 2011. ${ }^{74}$

†Postcode missing for 15 students, therefore socioeconomic status and remoteness could not be calculated. ARIA, Accessibility/Remoteness Index of Australia.

\section{Resilience protective factors}

The mean scores for each measure of student resilience protective factors are shown in table 4 . The means varied from 2.36 (SD 0.74) to 3.42 (SD 0.75).

\section{Correlation between resilience protective factors}

Significant correlations were found between all resilience protective factor subscale scores. Little to weak positive correlations between all individual (0.25-0.53) and environmental resilience protective factor subscales were found (0.26-0.61) (see online supplementary appendix A).

\section{Associations between resilience protective factor scores and substance use \\ Univariate associations}

With four exceptions, all measures of substance use were inversely associated with all individual and environmental resilience protective factor subscale scores (table 5).

\section{Multivariate associations}

The final multivariate model for each substance use measure contained between 4 and 10 of the 14 resilience protective factor subscales (table 6). Of the resilience protective factors that remained in each final model, the majority had an inverse association with substance use (table 6).

Across all substance use models, two protective factors were found to have an inverse association with substance use ('goals and aspirations' and 'prosocial peers'). A one-unit decrease in mean subscale score significantly increased the odds of smoking (both measures), having consumed alcohol (all three measures), having used marijuana or another illicit substance by between 1.20 and 1.65 times for 'goals and aspirations', and between 2.30 and 3.64 times for 'prosocial peers'.

Four resilience protective factors were inversely associated with at least one substance use measure ('home support' (5 of 7 substance use measures), 'school support' (3 of 7), 'self-awareness' (2 of 7), 'community meaningful participation' (2 of 7$)$ ). Two resilience protective factors were found to have a consistent positive association with at least one substance use measure ('community support' (3 of 7 substance use measures), 'peer caring relationships' (5 of 7)). The remaining six resilience protective factors were not associated with any substance use outcome.

Data for between 2 and 5 variables were missing for 81 of 10092 participants, with no identified pattern of missingness. Identical analyses using imputation for missing data did not show a differential pattern of results.

\section{DISCUSSION}

This study explored the associations between 14 adolescent individual and environmental resilience protective factors and seven measures of adolescent substance use. Of the 14 factors examined, 6 had an inverse and 2 had 
Table 3 Proportion of students reporting substance use by grade and sex $(n=10092)$

\begin{tabular}{|c|c|c|c|c|c|c|c|c|c|c|}
\hline Substance use & $\begin{array}{l}\text { All } \\
\text { students } \\
\%(n)\end{array}$ & $\begin{array}{l}\text { Grade } 7 \\
\%\end{array}$ & $\begin{array}{l}\text { Grade } 8 \\
\%\end{array}$ & $\begin{array}{l}\text { Grade } 9 \\
\%\end{array}$ & $\begin{array}{l}\text { Grade } 10 \\
\%\end{array}$ & p Value & $\begin{array}{l}\text { Male } \\
\%\end{array}$ & $\begin{array}{l}\text { Female } \\
\%\end{array}$ & p Value & $\begin{array}{l}\text { National } \\
\text { comparison } \\
\text { data }^{\star} \\
\%\end{array}$ \\
\hline $\begin{array}{l}\text { Ever used } \\
\text { tobacco }\end{array}$ & 22.5 (2272) & 11.2 & 20.0 & 29.8 & 35.0 & $<0.0001$ & 23.4 & 21.6 & 0.0920 & $23.3 \%$ \\
\hline $\begin{array}{l}\text { Recent tobacco } \\
\text { use }\end{array}$ & $6.9(700)$ & 2.3 & 6.1 & 9.7 & 12.2 & $<0.0001$ & 7.3 & 6.6 & 0.2724 & $6.7 \%$ \\
\hline $\begin{array}{l}\text { Ever consumed } \\
\text { alcohol } \dagger\end{array}$ & $50.5(5080)$ & 30.3 & 45.5 & 62.8 & 74.6 & $<0.0001$ & 54.2 & 46.8 & $<0.0001$ & $74.0 \%$ \\
\hline $\begin{array}{l}\text { Recent alcohol } \\
\text { usef }\end{array}$ & $13.6(1367)$ & 5.7 & 10.3 & 18.8 & 24.5 & $<0.0001$ & 15.9 & 11.3 & $<0.0001$ & $13.6 \%$ \\
\hline $\begin{array}{l}\text { Risk alcohol } \\
\text { use§ }\end{array}$ & $14.8(1488)$ & 5.2 & 11.6 & 19.4 & 29.0 & $<0.0001$ & 16.4 & 13.2 & $<0.0001$ & \\
\hline $\begin{array}{l}\text { Recent } \\
\text { marijuana useף }\end{array}$ & $6.3(630)$ & 1.5 & 4.7 & 9.4 & 12.2 & $<0.0001$ & 7.9 & 4.7 & $<0.0001$ & $6.8 \%$ \\
\hline $\begin{array}{l}\text { Recent other } \\
\text { illicit drug usef }\end{array}$ & $2.6(259)$ & 1.0 & 2.3 & 3.5 & 4.4 & $<0.0001$ & 3.3 & 1.9 & $<0.0001$ & $2.9 \%$ \\
\hline \multicolumn{11}{|c|}{$\begin{array}{l}{ }^{*} \text { Data from the } 2011 \text { Australian Secondary Students' Alcohol and Drug Survey }(n=26194) .{ }^{9} \\
\$ 35 \text { missing }(n=10057) . \\
\$ 37 \text { missing }(n=10055) . \\
\$ 40 \text { missing }(n=10052) . \\
\text { ๆ66 missing }(n=10026) .\end{array}$} \\
\hline
\end{tabular}

Table 4 Student mean resilience protective factor scores

\begin{tabular}{lll}
\hline & \multicolumn{2}{l}{$\begin{array}{l}\text { Protective } \\
\text { factor score }\end{array}$} \\
\cline { 2 - 3 } Protective factor & Mean & SD \\
\hline Individual protective factor subscales: & & \\
$\quad$ Cooperation and communication & 3.03 & 0.66 \\
Empathy & 2.98 & 0.71 \\
Goals and aspirations & 3.15 & 0.71 \\
Problem-solving & 2.78 & 0.70 \\
Self-awareness & 3.07 & 0.70 \\
Self-efficacy & 3.03 & 0.53 \\
Environmental protective factor subscales: & & \\
School support & 2.88 & 0.74 \\
School meaningful participation & 2.36 & 0.74 \\
Community support & 3.21 & 0.77 \\
Community meaningful participation & 3.02 & 0.85 \\
Home support & 3.38 & 0.61 \\
Home meaningful participation & 2.89 & 0.70 \\
Prosocial peers & 2.91 & 0.63 \\
Peer caring relationships & 3.42 & 0.75 \\
\hline
\end{tabular}

a positive association with at least one type of substance use. Of the resilience protective factors found to be inversely associated with substance use, only two were associated with all substance use measures. Such findings suggest that the protective benefit of resilience protective factors for adolescent substance use may be limited to only a small number of such factors and then, primarily, only for some substances.

No previous single peer-reviewed study has reported the associations between a comprehensive range of individual and environmental protective factor measures and a broad range of adolescent substance use measures. Nonetheless, the inverse associations found between eight of the individual and environmental protective factor measures and substance use are generally consistent with the direction of previous studies of single or small numbers of factors and substance use. ${ }^{23} 2930$ 47-50 58 Similarly, the findings of no association between six such factors and substance use are consistent with previous studies. ${ }^{27} 4864$ In contrast, the consistent positive association found between the protective factors of 'peer caring relationships' and use of some substances differs from a previous study that has reported no evidence of an association. ${ }^{30}$ While the reason for such contrast is unknown, it may be at least partly attributable to the different measurement of resilience protective factors and substance use between studies. ${ }^{30}$ No previous studies could be identified that examined the association between adolescent substance use and 'community support'. Further research is required to confirm the contrasting findings and, if confirmed, to understand the mechanisms for such an association such that interventions promoting these factors do not have an untoward effect.

The findings that six factors conferred a protective benefit for adolescent substance use appear to align with models of adolescent substance use prevention, such as the social development model (grounded in Bandura's social learning theory and control theory) ${ }^{19}$ and models of resilience, $2325293640-4475$ which focus on individual capacities or assets, and bonding with family, school and peers as protection against the risk factors for substance use. However, despite the consistency in the direction of such associations, there was a 
$\underline{\text { Table } 5 \text { Univariate associations between mean resilience protective factor scores and substance use }{ }^{\star} \dagger}$

\begin{tabular}{|c|c|c|c|c|c|c|c|}
\hline Protective factor & $\begin{array}{l}\text { Ever used tobacco } \\
\text { OR }(95 \% \mathrm{Cl})\end{array}$ & $\begin{array}{l}\text { Recent tobacco } \\
\text { use } \\
\text { OR }(95 \% \mathrm{Cl}) \\
\end{array}$ & $\begin{array}{l}\text { Ever used alcoholł } \\
\text { OR }(95 \% \mathrm{Cl})\end{array}$ & $\begin{array}{l}\text { Recent alcohol } \\
\text { use§ } \\
\text { OR }(95 \% \mathrm{Cl}) \\
\end{array}$ & $\begin{array}{l}\text { Risk alcohol useๆ } \\
\text { OR }(95 \% \mathrm{Cl})\end{array}$ & $\begin{array}{l}\text { Marijuana use }{ }^{\star \star} \\
\text { OR }(95 \% \mathrm{Cl})\end{array}$ & $\begin{array}{l}\text { Other illicit drug } \\
\text { use } \\
\text { OR }(95 \% \mathrm{Cl})\end{array}$ \\
\hline \multicolumn{8}{|l|}{ Individual protective factors: ${ }^{* *}$} \\
\hline $\begin{array}{l}\text { Cooperation and } \\
\text { communication }\end{array}$ & $1.65+\dagger(1.50$ to 1.81$)$ & $1.81 \dagger \dagger(1.57$ to 2.08$)$ & $1.42 \dagger \dagger(1.32$ to 1.52$)$ & $1.48+\dagger(1.32$ to 1.66$)$ & $1.14 \dagger \dagger(1.29$ to 1.55$)$ & $1.79+\dagger(1.52$ to 2.12$)$ & $2.22 \dagger \dagger(1.78$ to 2.77$)$ \\
\hline Empathy & $1.35+\dagger(1.23$ to 1.49$)$ & $1.47 \dagger \dagger(1.24$ to 1.73$)$ & $1.39+\dagger(1.29$ to 1.50$)$ & $1.38 \dagger \dagger(1.23$ to 1.55$)$ & $1.40 \dagger \dagger(1.26$ to 1.54$)$ & $1.53+\dagger(1.31$ to 1.79$)$ & $2.15 \dagger \dagger(1.68$ to 2.75$)$ \\
\hline Goals and aspirations & $1.76 \dagger \dagger(1.64$ to 1.90$)$ & $2.23+\dagger$ (1.97 to 2.53 ) & $1.71 \dagger \dagger(1.56$ to 1.87$)$ & $1.73 \dagger \dagger(1.60$ to 1.88$)$ & $1.97 \dagger \dagger(1.82$ to 2.15$)$ & $1.93+\dagger$ (1.68 to 2.21$)$ & $2.30 \dagger \dagger$ ( 1.89 to 2.79 ) \\
\hline Problem-solving & $1.66+\dagger(1.54$ to 1.80$)$ & $1.75+\dagger(1.49$ to 2.05$)$ & $1.53+\dagger(1.43$ to 1.63$)$ & $1.60 \dagger+(1.45$ to 1.76$)$ & $1.54 \uparrow \dagger(1.42$ to 1.67$)$ & $1.95+\dagger$ (1.69 to 2.26$)$ & $2.50+\dagger$ (1.99 to 3.15$)$ \\
\hline Self-awareness & $1.84 \dagger \dagger$ (1.69 to 2.01$)$ & $2.03+\dagger$ (1.77 to 2.32$)$ & $1.58+\dagger(1.46$ to 1.71$)$ & $1.58+\dagger(1.42$ to 1.74$)$ & $1.58+\dagger(1.43$ to 1.74$)$ & $1.91+\dagger(1.65$ to 2.20$)$ & $2.18+\dagger(1.72$ to 2.75$)$ \\
\hline Self-efficacy & $1.95+\dagger(1.77$ to 2.15$)$ & $2.21+\dagger(1.79$ to 2.72$)$ & $1.65+\dagger(1.50$ to 1.81$)$ & $1.59+\dagger(1.39$ to 1.82$)$ & $1.68+\dagger(1.50$ to 1.89$)$ & $1.84 \dagger \dagger(1.51$ to 2.24$)$ & $2.56+\dagger(1.93$ to 3.41$)$ \\
\hline \multicolumn{8}{|c|}{ Environmental protective factors:** } \\
\hline School support & $1.76+\dagger(1.63$ to 1.89$)$ & $1.80 \dagger \dagger(1.58$ to 2.05$)$ & $1.73+\dagger(1.61$ to 1.85$)$ & $1.60 \dagger \dagger(1.47$ to 1.74$)$ & $1.68+\dagger(1.53$ to 1.86$)$ & $1.86+\dagger(1.61$ to 2.15$)$ & $2.11+\dagger(1.68$ to 2.67$)$ \\
\hline $\begin{array}{l}\text { School meaningful } \\
\text { participation }\end{array}$ & $1.66+\dagger(1.53$ to 1.81$)$ & $1.79+\dagger(1.54$ to 2.08$)$ & $1.45+\dagger(1.36$ to 1.56$)$ & $1.45+\dagger(1.28$ to 1.64$)$ & $1.46+\dagger(1.32$ to 1.61$)$ & $1.87 \dagger \dagger(1.63$ to 2.16$)$ & $1.98+\dagger(1.48$ to 2.65$)$ \\
\hline Community support & $1.38+\dagger(1.30$ to 1.46$)$ & $1.39+\dagger(1.24$ to 1.56$)$ & $1.26+\dagger(1.20$ to 1.33$)$ & $1.27 \dagger \dagger(1.18$ to 1.36$)$ & $1.21 \dagger \dagger(1.11$ to 1.32$)$ & $1.43+\dagger(1.29$ to 1.59$)$ & $1.77 \dagger \dagger(1.49$ to 2.10$)$ \\
\hline $\begin{array}{l}\text { Community meaningful } \\
\text { participation }\end{array}$ & $1.51 \mathrm{t}+(1.42$ to 1.63$)$ & $1.69+\dagger(1.53$ to 1.87$)$ & $1.27 \dagger \dagger(1.20$ to 1.35$)$ & $1.26+\dagger(1.18$ to 1.34$)$ & $1.32 \dagger \dagger(1.23$ to 1.42$)$ & $1.48+\dagger(1.35$ to 1.63$)$ & $1.69+\dagger(1.51$ to 1.90$)$ \\
\hline Home support & $2.25+\dagger$ (2.07 to 2.45 ) & $2.19+\dagger$ (1.89 to 2.52$)$ & $2.21 \dagger \dagger$ (2.02 to 2.41$)$ & $2.07 \dagger \dagger(1.88$ to 2.29$)$ & $2.07 \dagger \dagger$ (1.89 to 2.28$)$ & $2.27 \dagger \dagger$ (1.96 to 2.63 ) & $2.63+\dagger$ (2.08 to 3.34 ) \\
\hline Home meaningful participation & $1.71+\dagger(1.55$ to 1.87$)$ & $1.81+\dagger(1.55$ to 2.11$)$ & $1.49+\dagger(1.37$ to 1.61$)$ & $1.41+\dagger(1.27$ to 1.58$)$ & $1.46+\dagger(1.34$ to 1.60$)$ & $1.84 \dagger \dagger(1.61$ to 2.10$)$ & $2.02+\dagger(1.59$ to 2.57$)$ \\
\hline Peer caring relationships & $1.14 \uparrow \dagger(1.07$ to 1.22$)$ & 1.18 (1.06 to 1.32$)$ & $1.04(0.98$ to 1.10$)$ & $1.11(1.01$ to 1.22$)$ & $1.07(0.99$ to 1.16$)$ & $1.27 \dagger \dagger(1.13$ to 1.43$)$ & $1.53+\dagger(1.28$ to 1.77$)$ \\
\hline Prosocial peers & $3.19+\dagger(2.85$ to 3.58$)$ & $3.82 \dagger \dagger$ (3.20 to 4.56$)$ & $2.79+\dagger(2.51$ to 3.10$)$ & $2.92 \dagger \dagger(2.58$ to 3.30$)$ & $3.15+\dagger$ ( 2.76 to 3.59$)$ & $3.75+\dagger$ (3.32 to 4.23$)$ & $4.26+\dagger$ (3.41 to 5.31$)$ \\
\hline
\end{tabular}




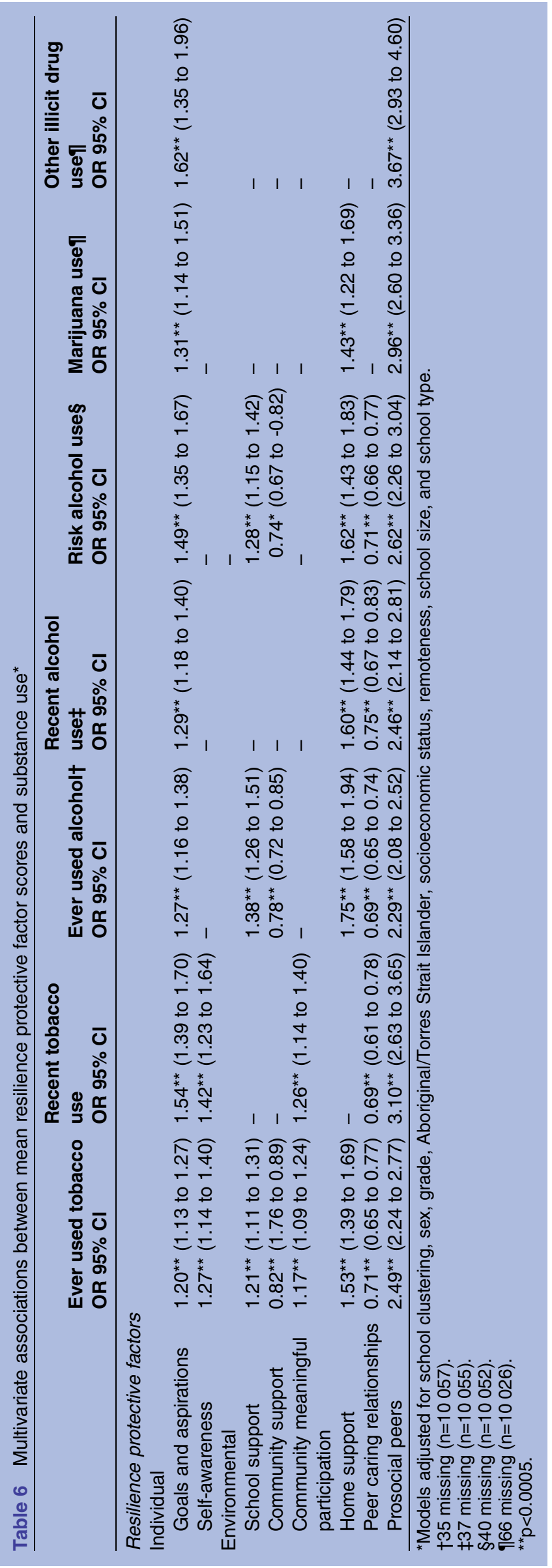

lack of consistency of association across types of substances. For example, lower 'community meaningful participation' was only associated with tobacco use (ever and recent) and lower 'school support' only associated with some measures of tobacco (ever) and alcohol use (ever and risk). Such findings suggest that the protective benefit of such factors is variable across different types of substance use, rather than being generalised. The finding of no association or a positive association between a number of resilience protective factors and substance use, however, may challenge such models of substance use prevention, or at least the breadth of factors described by such models.

The finding of an inverse association between some resilience protective factors and different forms of adolescent substance use suggests that interventions and programmes that seek to reduce such use by increasing resilience protective factors may be more likely to be effective if they target specific protective factors to address specific types of substance use. A number of studies have demonstrated that interventions can successfully increase resilience protective factors among young people ${ }^{76-79}$ including individual factors such as self-efficacy, ${ }^{80}$ and environmental factors related to family and community connection. ${ }^{77}$ For example, a randomised controlled trial in Hong Kong examining the efficacy of a positive youth development intervention targeting a range of resilience protective factors (including self-efficacy, beliefs in the future, bonding and prosocial involvement) to reduce adolescent substance use, reported an increase in some targeted protective factors (such as self-efficacy and bonding) and decreases in substance use. ${ }^{80}$ Further research is required to determine whether intervention approaches focused on the enhancement of the specific resilience protective factors found to be associated with adolescent substance use in this study have a beneficial effect on such use.

As previous research has demonstrated that risk factors such as access to substances, substance use by parents and by peers and siblings ${ }^{18-22}$ are associated with adolescent substance use; further research exploring the association of resilience protective factors with adolescent substance use in the context of such risk factors is warranted. Such research is needed to identify the specific set of individual and environmental resilience protective factors and risk factors that are associated with each type of adolescent substance use, the relative contribution of each factor, and to determine the consistency of association between such factors and different types of substances. While some studies investigating risk and protective factors generally have found risk factors to be stronger predictors of tobacco, alcohol and marijuana use, such studies have only examined a limited number of resilience protective factors and types of substance use. ${ }^{4981}$ Additionally, future research investigating the potential of such factors for prevention should be theory driven in an effort to understand the 
aetiology of substance use, and whether this differs by substance use type.

The findings of this study should be viewed in light of a number of the study characteristics. First, the study included a number of design strengths, including: a large sample of adolescents; use of a tool validated in an Australian adolescent population; comprehensive measurement of individual and environmental resilience protective factors; use of multiple accepted measures of substance use and analyses that accounted for a range of known confounders and potential clustering effects within schools. Although the study was reliant on adolescent self-report of substance use and subject to the known limitations of self-report in this population, ${ }^{81}$ selfreport is an accepted method of measuring substance use by adolescents. To optimise validity of report, a webbased survey was used ${ }^{82}$ as was confidential participation by students, strategies that have been found to increase the validity of adolescent report of sensitive questions, such as substance use. ${ }^{83}$

Although a non-response bias may exist, the demographic characteristics and prevalence of adolescent substance use found in this study are consistent with those reported in Australian triennial nationwide surveys, ${ }^{9}$ and suggests that the likelihood of bias may be limited. The conduct of the study in one local health district of New South Wales, Australia, may limit the generalisability of the results to other adolescent populations, and while the imbalance in the proportion of Aboriginal and Torres Strait Islander and Grade 10 students may be indicative of this, the impact is not known. Finally, the study is limited by its cross-sectional design which does not allow for investigation of the causal pathways of the association findings. Further longitudinal and intervention-based research is required to address these questions.

\author{
Author affiliations \\ ${ }^{1}$ Hunter New England Population Health, Wallsend, New South Wales, \\ Australia \\ ${ }^{2}$ School of Medicine and Public Health, The University of Newcastle, \\ University Drive, Callaghan, New South Wales, Australia \\ ${ }^{3}$ Hunter Medical Research Institute, New Lambton, New South Wales, \\ Australia \\ ${ }^{4}$ Priority Research Centre Health Behaviour, The University of Newcastle, \\ University Drive, Callaghan, New South Wales, Australia \\ ${ }^{5}$ School of Psychology, The University of Newcastle, University Drive, \\ Callaghan, New South Wales, Australia
}

Acknowledgements With thanks to the staff and students from participating schools, the Healthy Schools Healthy Futures project team and Christophe Lecathelinais (Hunter New England Population Health) for statistical support. This work was supported by in-kind support from Hunter New England Population Health and the Hunter Medical Research Institute.

Contributors RKH contributed to the design of the data collection tools, monitored the data collection, led conception of the paper, cleaned and analysed the data, drafted and revised the paper. MF, JB and JW contributed to the design of the data collection tools and conception of the paper, monitored the data collection, provided critical revision and approved the final version of the paper. LW, KG and JD contributed to the critical revision of the manuscript and approved the final manuscript. CL provided statistical advice.
Funding This work was supported by the National Health and Medical Research Council of Australia (grant number NHMRC \#1016650) and the nib Foundation.

Competing interests None declared.

Ethics approval Human Research Ethics Committee, Hunter New England Health (Ref:09/11/18/4.01) and Human Research Ethics Committee, University of Newcastle (Ref:H-2010-0029).

Provenance and peer review Not commissioned; externally peer reviewed.

Data sharing statement Requests for additional unpublished data should be forwarded to rebecca.hodder@hnehealth.nsw.gov.au

Open Access This is an Open Access article distributed in accordance with the Creative Commons Attribution Non Commercial (CC BY-NC 4.0) license, which permits others to distribute, remix, adapt, build upon this work noncommercially, and license their derivative works on different terms, provided the original work is properly cited and the use is non-commercial. See: http:// creativecommons.org/licenses/by-nc/4.0/

\section{REFERENCES}

1. Mathers C, Boerma T, Ma Fat D. The global burden of disease: 2004 update. Geneva, Switzerland: World Health Organisation, 2008.

2. Rehm J, Mathers C, Popova S, et al. Global burden of disease and injury and economic cost attributable to alcohol use and alcohol-use disorders. Lancet 2009;373:2223-33.

3. National Drug Intelligence Center. The economic impact of illicit drug use on American Society. Washington, DC: United States Department of Justice, 2011.

4. Centers for Disease Control and Prevention. Smoking-attributed mortality, years of potential life lost, and productivity losses-United States 2000-2004. Morbidity and Mortality Weekly Report. 2008.

5. National Institute on Drug Abuse. DrugFacts: Understanding Drug Abuse and Addiction. http://www drugabuse gov/publications/ drugfacts/understanding-drug-abuse-addiction. 2012. (accessed 18 Dec 2013).

6. Collins DJ, Lapsley HM. The costs of tobacco, alcohol and illicit drug abuse to Australian society in 2004/05. Canberra, Australia: Commonwealth of Australia, 2008.

7. Gilman SE, Abrams DB, Buka SL. Socioeconomic status over the life course and stages of cigarette use: initiation, regular use, and cessation. J Epidemiol Community Health 2003;57:802-8.

8. Johnston LD, O'Malley PM, Bachman JG, et al. Monitoring the future. National results on adolescent drug use: overview of key findings, 2007 (NIH Publication No. 08-6418). Bethesda, MD, National Institute on Drug Abuse, 2008.

9. White V, Bariola E. Australian secondary schools students' use of tobacco, alcohol and over-the-counter and illicit substances in 2011.2012. http://www.nationaldrugstrategy.gov.au/internet/ drugstrategy/Publishing.nsf/content/BCBF6B2C638E1202CA257 ACD0020E35C/\$File/National\%20Report FINAL ASSAD 7.12.pdf (accessed 19 Mar 2013)

10. Donovan JE. Adolescent alcohol initiation: A review of psychosocial risk factors. J Adolesc Health 2004;35:529.

11. Reidpath DD, Davey TM, Kadirvelu A, et al. Does one cigarette make an adolescent smoker, and is it influenced by age and age of smoking initiation? Evidence of association from the US Youth Risk Behavior Surveillance System (2011). Prev Med 2014;59:37-41.

12. von Sydow $\mathrm{K}$, Lieb $\mathrm{R}$, Pfister $\mathrm{H}$, et al. What predicts incident use of cannabis and progression to abuse and dependence? A 4-year prospective examination of risk factors in a community sample of adolescents and young adults. Drug Alcohol Depend 2002;68:49-64.

13. Eaton DK, Kann L, Kinchen S, et al. Centers for Disease Control and Prevention. Youth Risk Behavior Surveillance-United States, 2011. MMWR Surveill Summ 2012;61:1-162.

14. Henderson $\mathrm{H}$, Nass L, Payne $\mathrm{C}$, et al. Smoking, drinking and drug use among young people in England 2012. London: Health and Social Care Information Centre, 2013.

15. Canadian Centre on Substance Abuse. Building on our strengths: Canadian standards for school-based youth substance abuse prevention. Ottawa, ON: Canadian Centre on Substance Abuse, 2010version 2.0.

16. Executive Office of the President on the United States. National drug control strategy. Washington, DC: The White House, 2013. 
17. Ministerial Council on Drug Strategy. National drug strategy 20102015: a framework for action on alcohol, tobacco and other drugs. Canberra: ACT, Commonwealth of Australia, 2011.

18. Catalano RF, Hawkins JD, Berglund ML, et al. Prevention science and positive youth development: competitive or cooperative frameworks? J Adolesc Health 2002;31(Suppl 6):230-9.

19. Hawkins JD, Catalano RF, Miller JY. Risk and protective factors for alcohol and other drug problems in adolescence and early adulthood: implications for substance abuse prevention. Psychol Bull 1992;112:64-105.

20. Dierker LC, Avenevoli S, Goldberg A, et al. Defining subgroups of adolescents at risk for experimental and regular smoking. Prev Sci 2004:5:169-83.

21. Dielman TE, Butchart AT, Shope JT, et al. Environmental correlates of adolescent substance use and misuse: implications for prevention programs. Int J Addict 1990;25:855-80.

22. Tyas SL, Pederson LL. Psychosocial factors related to adolescent smoking: a critical review of the literature. Tob Control 1998;7:409-20.

23. Resnick MD, Bearman PS, Blum RW, et al. Protecting adolescents from harm. Findings from The National Longitudinal Study on Adolescent Health. JAMA 1997;278:823-32.

24. Kavas AB. Self-esteem and health-risk behaviors among Turkish late adolescents. Adolescence 2009;44:187-98.

25. Wiefferink $\mathrm{CH}$, Peters L, Hoekstra F, et al. Clustering of health-related behaviors and their determinants: possible consequences for school health interventions. Prev Sci 2006;7:127-49.

26. Patton GC, Bond L, Carlin JB, et al. Promoting social inclusion in schools: a group-randomized trial of effects on student health risk behavior and well-being. Am J Public Health 2006;96:1582-7.

27. Fang L, Barnes-Ceeney K, Schinke SP. Substance use behavior among early-adolescent Asian American girls: the impact of psychological and family factors. Women Health 2011;51:623-42.

28. Carvajal SC, Granillo TM. A prospective test of distal and proximal determinants of smoking initiation in early adolescents. Addict Behav 2006;31:649-60.

29. Bond L, Butler H, Thomas L, et al. Social and school connectedness in early secondary school as predictors of late teenage substance use, mental health, and academic outcomes. J Adolesc Health 2007;40:357.e9-357.e18

30. McLellan L, Rissel C, Donnelly N, et al. Health behaviour and the school environment in New South Wales, Australia. Soc Sci Med 1999;49:611-19.

31. Jessor R, Van Den Bos J, Vanderryn J, et al. Protective factors in adolescent problem behavior: moderator effects and developmental change. Developmental Psychology 1995;31:923-33.

32. Neumark-Sztainer D, Story M, French SA, et al. Psychosocial correlates of health compromising behaviors among adolescents. Health Educ Res 1997:12:37-52.

33. Vuille JC, Schenkel M. Social equalization in the health of youth The role of the school. Eur J Public Health 2001;11:287-93.

34. Haegerich TM, Tolan PH. Core competencies and the prevention of adolescent substance use. New Dir Child Adolesc Dev 2008;2008:47-60.

35. Simons-Morton B, Crump AD, Haynie DL, et al. Psychosocial, school, and parent factors associated with recent smoking among early-adolescent boys and girls. Prev Med 1999;28:138-48.

36. Benard B. Fostering Resiliency in Urban Schools. Closing the achievement gap: A vision for changing beliefs and practices. Virginia: Association for Supervision and Curriculum Development, 1996.

37. Lee TY, Cheung CK, Kwong WM. Resilience as a positive youth development construct: a conceptual review. ScientificWorldJournal 2012;2012:390450.

38. Brownlee K, Rawana J, Franks J, et al. A systematic review of strengths and resilience outcome literature relevant to children and adolescents. Child Adolesc Soc Work J 2013;30:435-59.

39. Fergus S, Zimmerman MA. Adolescent resilience: a framework for understanding healthy development in the face of risk. Annu Rev Public Health 2005;26:399-419.

40. Bernat DH, Resnick MD. Healthy youth development: science and strategies. J Public Health Manag Pract 2006(Suppl):S10-16.

41. Toumbourou JW. Drug prevention strategies: a developmental settings approach prevention research evaluation report number 2. Melbourne: Australian Drug Foundation, 2002.

42. Harvey J, Delfabbro PH. Psychological resilience in disadvantaged youth: a critical overview. Aust Psychol 2004;39:3-13.

43. Masten AS. Ordinary magic. Resilience processes in development Am Psychol 2001;56:227-38.
44. Masten AS, Best KM, Garmezy N. Resilience and development: Contributions from the study of children who overcome adversity. Dev Psychopathol 1990;2:425-44.

45. Arpawong TE, Sun P, Chang MC, et al. Family and personal protective factors moderate the effects of adversity and negative disposition on smoking among Chinese adolescents. Subst Use Misuse 2010:45:1367-89.

46. Beyers JM, Toumbourou JW, Catalano RF, et al. A cross-national comparison of risk and protective factors for adolescent substance use: the United States and Australia. J Adolesc Health 2004;35:3-16.

47. Grunbaum JA, Tortolero S, Weller N, et al. Cultural, social, and intrapersonal factors associated with substance use among alternative high school students. Addict Behav 2000;25:145-51.

48. Guo J, Hill KG, Hawkins JD, et al. A developmental analysis of sociodemographic, family, and peer effects on adolescent illicit drug initiation. J Am Acad Child Adolesc Psychiatry 2002;41:838-45.

49. Hemphill SA, Heerde JA, Herrenkohl TI, et al. Risk and protective factors for adolescent substance use in Washington state, the United States and Victoria, Australia: a longitudinal study. J Adolesc Health 2011;49:312-20.

50. Kirk CM, Lewis RK, Lee FA, et al. The power of aspirations and expectations: the connection between educational goals and risk behaviors among African American adolescents. J Prev Interv Community 2011;39:320-32.

51. Kogan SM, Luo Z, Murry VM, et al. Risk and protective factors for substance use among African American high school dropouts. Psychol Addict Behav 2005;19:382-91.

52. Kuntsche EN, Kuendig $\mathrm{H}$. What is worse? A hierarchy of family-related risk factors predicting alcohol use in adolescence. Subst Use Misuse 2006;41:71-86.

53. Lac A, Unger JB, Basáñez T, et al. Marijuana use among Latino adolescents: gender differences in protective familial factors. Subst Use Misuse 2011;46:644-55

54. Ludden AB, Eccles JS. Psychosocial, motivational and contextual profiles of youth reporting different patterns of substance use during adolescence. J Res Adolesc 2007;17:51-88.

55. Luk JW, Farhat T, lannotti RJ, et al. Parent-child communication and substance use among adolescents: do father and mother communication play a different role for sons and daughters? Addict Behav 2010;35:426-31.

56. Mouttapa M, Weiss JW, Hermann M. Is image everything? The role of self-image in the relationship between family functioning and substance use among Hispanic adolescents. Subst Use Misuse 2009;44:702-21.

57. O'Loughlin J, Karp I, Koulis T, et al. Determinants of first puff and daily cigarette smoking in adolescents. Am J Epidemiol 2009;170:585-97.

58. Oman RF, Vesely S, Aspy CB, et al. The potential protective effect of youth assets on adolescent alcohol and drug use. Am J Public Health 2004:94:1425-30.

59. Ostaszewski K, Zimmerman MA. The effects of cumulative risks and promotive factors on urban adolescent alcohol and other drug use: a longitudinal study of resiliency. Am J Community Psychol 2006;38:237-49.

60. Otten R, van Lier PA, Engels RC. Disentangling two underlying processes in the initial phase of substance use: Onset and frequency of use in adolescent smoking. Addict Behav 2011;36:237-40.

61. Perra O, Fletcher A, Bonell C, et al. School-related predictors of smoking, drinking and drug use: evidence from the Belfast Youth Development Study. J Adolesc 2012;35:315-24.

62. Piko BF, Kovacs E. Do parents and school matter? Protective factors for adolescent substance use. Addict Behav 2010;35:53-6.

63. Scheier LM, Botvin GJ, Griffin KW, et al. Dynamic growth models of self-esteem and adolescent alcohol use. The Journal of Early Adolescence 2000;20:178-209.

64. Stephens PC, Sloboda Z, Stephens RC, et al. Universal school-based substance abuse prevention programs: Modeling targeted mediators and outcomes for adolescent cigarette, alcohol and marijuana use. Drug Alcohol Depend 2009;102:19-29.

65. Veselska Z, Geckova AM, Orosova O, et al. Self-esteem and resilience: the connection with risky behavior among adolescents. Addict Behav 2009;34:287-91.

66. Centre for Epidemiology and Evidence. Australian bureau of statistics population estimates (SAPHaRI). Sydney: NSW Ministry of Health, 2012.

67. Hodder RK, Freund M, Bowman J, et al. A cluster randomized trial of a school-based resilience intervention to decrease tobacco, alcohol and illicit drug use in secondary school students: study protocol. BMC Public Health 2012;12:1009. 
68. Trewin D. Information paper census of population and housing socio-economic indexes for areas: Australia 2001. Canberra: Australian Bureau of Statistics: Commonwealth of Australia, 2003

69. Hanson TL, Kim JO. Measuring resilience and youth development the psychometric properties of the Healthy Kids Survey. Washington, DC: US Department of Education, Institute of Education Sciences, National Centre for Education Evaluation and Regional Assistance, Regional Educational Laboratory West, 2007.

70. Department of Health and Aged Care. Measuring remoteness: accessibility/remoteness index of Australia (ARIA). Canberra: Australian Government, 2001.

71. Hubbard AE, Ahern J, Fleischer NL, et al. To GEE or not to GEE: comparing population average and mixed models for estimating the associations between neighborhood risk factors and health. Epidemiology 2010;21:467-74

72. Hardin JW, Hilbe JM. Generalised estimating equations. 2nd edn. Florida, USA: Chapman and Hall/CRC, 2012.

73. Hawthorne G, Elliott P. Imputing cross-sectional missing data: comparison of common techniques. Aust N Z J Psychiatry 2005;39:583-90.

74. Australian Bureau of Statistics. 4221.0 - Schools, Australia, 2013. 2014. Commonwealth of Australia. http://www.abs.gov.au/AUSSTATS

75. Luthar SS, Cicchetti D, Becker B. The construct of resilience: a critical evaluation and guidelines for future work. Child Dev 2000;71:543-62.
76. King KA, Vidourek RA, Davis B, et al. Increasing self-esteem and school connectedness through a multidimensional mentoring program. J Sch Health 2002;72:294-9.

77. Lee PC, Stewart DE. Does a socio-ecological school model promote resilience in primary schools? J Sch Health 2013;83: 795-804.

78. Lynch K, Geller S, Schmidt M. Multi-year evaluation of the effectiveness of a resilience-based prevention program for young children. J Prim Prev 2004;24:335-53.

79. Steinhardt M, Dolbier C. Evaluation of a resilience intervention to enhance coping strategies and protective factors and decrease symptomatology. J Am Coll Health 2008;56:445-53.

80. Shek DTL, Ma CMS. Impact of Project P.A.T.H.S. on adolescent developmental outcomes in Hong Kong: findings based on seven waves of data. Int J Adolesc Med Health 2012;24:231-44.

81. Murray DM, Perry CL. The measurement of substance use among adolescents: when is the 'bogus pipeline' method needed? Addict Behav 1987;12:225-33

82. Wang YC, Lee CM, Lew-Ting CY, et al. Survey of substance use among high school students in Taipei: web-based questionnaire versus paper-and-pencil questionnaire. J Adolesc Health 2005;37:289-95.

83. O'Malley PM, Johnston LD, Bachman JG, et al. A comparison of confidential versus anonymous survey procedures: effects on reporting of drug use and related attitudes and beliefs in a national study of students. J Drug Issues 2000;30:35-54. 